\title{
Effects of ocean acidification on the calcification of otoliths of larval Atlantic cod Gadus morhua
}

\author{
R. H. Maneja ${ }^{1, *}$, A. Y. Frommel ${ }^{1}$, A. J. Geffen ${ }^{2}$, A. Folkvord ${ }^{2}$, U. Piatkowski ${ }^{1}$, \\ M. Y. Chang ${ }^{2}$, C. Clemmesen ${ }^{1}$ \\ ${ }^{1}$ GEOMAR, Helmholtz Center for Ocean Research Kiel, Düsternbrooker Weg 20, Kiel 24105, Germany \\ ${ }^{2}$ Department of Biology, University of Bergen, PO Box 7803, Bergen 5020, Norway
}

\begin{abstract}
The growth and development of the aragonitic $\mathrm{CaCO}_{3}$ otoliths of teleost fish could be vulnerable to processes resulting from ocean acidification. The potential effects of an increase in atmospheric $\mathrm{CO}_{2}$ on the calcification of the otoliths were investigated by rearing Atlantic cod Gadus morhua L. larvae in $3 \mathrm{pCO}_{2}$ concentrations - control $(370 \mu \mathrm{atm})$, medium (1800 $\left.\mu \mathrm{atm}\right)$ and high (4200 $\mu \mathrm{atm})$ - from March to May 2010. Increased otolith growth was observed in 7 to $46 \mathrm{~d}$ post hatch (dph) cod larvae at elevated $\mathrm{pCO}_{2}$ concentrations. The sagittae and lapilli were usually largest in the high $\mathrm{pCO}_{2}$ treatment followed by the medium and control treatments. The greatest difference in mean otolith surface area (normalized to fish length) was for sagittae at $11 \mathrm{dph}$, with medium and high treatments being 46 and $43 \%$ larger than the control group, respectively. There was no significant $\mathrm{pCO}_{2}$ effect on the shape of the otoliths nor were there any trends in the fluctuating asymmetry, defined as the difference between the right and left sides, in relation to the increase in otolith growth from elevated $\mathrm{pCO}_{2}$.
\end{abstract}

KEY WORDS: Otolith growth/calcification - Ocean acidification · Atlantic cod larvae . Gadus morhua L.

Resale or republication not permitted without written consent of the publisher

\section{INTRODUCTION}

The Atlantic cod Gadus morhua L. is a northern temperate species, living in a region that is projected to be highly sensitive to future increases in atmospheric $\mathrm{CO}_{2}$. This is due to higher solubility of $\mathrm{CO}_{2}$ at low water temperatures, increased air-sea exchange as sea-ice loss increases from global warming, $\mathrm{CO}_{2}$ remineralization of high organic carbon loads from seasonal primary production and low-alkalinity riverine inputs (Fabry et al. 2009). Upwelling events in coastal waters could enhance the levels of ocean acidification by bringing deeper acidic waters with remineralized $\mathrm{CO}_{2}$ to the surface, as reported in the bay and inner shelf of the Gulf of Alaska in September 2008 (Fabry et al. 2009) and in Kiel Fjord during summer and autumn in 2008 (Thomsen et al. 2010). The major spawning area of the Arcto-Norwegian cod, the largest cod population in the world, is located around the Lofoten archipelago in Norway, including Vestfjorden, which is also subject to wind-driven upwelling and downwelling events (Furnes \& Sundby 1981). Upwelling caused by winds blowing from the southwest spreads the eggs out toward the central part of Vestfjorden, while downwelling due to winds from the northeast concentrates the older egg stages toward the shore. Wind-driven upwelling and downwelling events along the Norwegian coast also play a role in the dispersal and retention of planktonic organisms and early life stages of fish between the fjords and the Norwegian Coastal Current (Asplin et al. 1999). Accumulation of high- $\mathrm{pCO}_{2}$ bottom water, which can be upwelled to the surface, along the Norwegian Sea and Barents Sea is also possible. Both regions act as carbon sinks from the first part 
of the year until the end of summer (Findlay et al. 2008, Bates et al. 2009).

Teleost fishes produce otolith structures that are mainly composed of aragonitic $\mathrm{CaCO}_{3}$ (Degens et al. 1969), which may be sensitive to elevated levels of $\mathrm{pCO}_{2}$. Munday et al. (2011a) discussed 3 possible consequences of ocean acidification on otolith calcification. First, fish might have more difficulty in precipitating aragonite as the available carbonate ion concentration declines in seawater. Second, otolith hypercalcification might result from increased concentrations of carbonate and bicarbonate ions inside the endolymph due to the maintenance of internal $\mathrm{pH}$ by the fish regulatory mechanism with increased ambient $\mathrm{pCO}_{2}$. Third, physiological stress from acidic conditions could indirectly influence otolith shape and symmetry. Otolith hypercalcification was reported in white sea bass larvae Atractoscion nobilis at 993 and $2558 \mu \mathrm{atm} \mathrm{CO}_{2}$ (Checkley et al. 2009) and clownfish larvae Amphiprion percula at 1721 ratm (Munday et al. 2011a). In contrast, otolith calcification was not affected in spiny damselfish Acanthochromis polyacanthus juveniles grown at $850 \mu \mathrm{atm}$ $\mathrm{CO}_{2}$ (Munday et al. 2011b).

In the present study, the influence of elevated seawater $\mathrm{pCO}_{2}$ and the associated shift in carbonate chemistry equilibrium on the calcification of the otoliths of early life stages of Atlantic cod was investigated. The morphology of the otoliths is highly important for the normal acoustic and behavior functions in fish (Gauldie 1988, Lombarte 1992, Aguirre 2003), and abnormal otoliths may ultimately represent an added mortality risk. Understanding the influence of external environmental factors on the growth of the otoliths is also important because otoliths are widely used in fish studies, such as age determination, larval fish ecology and growth studies (Campana 2005).

\section{MATERIALS AND METHODS}

\section{Seawater manipulation}

The experiment was conducted in land-based mesocosms at the University of Bergen's Espegrend Marine Station from March to May 2010. Computercontrolled bubbling of $\mathrm{CO}_{2}$ into the bottom of nine 26501 experimental tanks was done to achieve 3 $\mathrm{pCO}_{2}$ levels: control $(370 \mu \mathrm{atm})$, medium $(1800 \mu \mathrm{atm})$ and high (4200 $\mu \mathrm{atm})$, with 3 replicates for each treatment level (see supplementary Table 4 in Frommel et al. 2012). A stable rise of temperature from $5^{\circ} \mathrm{C}$ in March to $10^{\circ} \mathrm{C}$ in May was achieved by placing the experimental tanks inside 2 water baths, which minimized the influence of fluctuations in air temperature. The gradual rise in temperature reflected the natural increase in water temperature of the fjord at $40 \mathrm{~m}$ depth, which was the source of the water with mean salinity of 33.3 supplied to the experimental tanks using a flow-through system. For further details, see Frommel et al. (2012).

\section{Larval rearing}

Newly fertilized Norwegian coastal cod eggs sourced from Parisvatnet Field Station of the Norwegian Institute of Marine Research were transferred to the floating incubation buckets in the experimental tanks on March 25, 2010. The eggs remained under normal $\mathrm{pCO}_{2}$ conditions for $3 \mathrm{~d}$, after which the $\mathrm{pCO}_{2}$ levels were adjusted to the targeted $\mathrm{pCO}_{2}$ for each treatment. Fifty percent hatching occurred on April 9, 2010, and that date was designated as $0 \mathrm{~d}$ post hatch (dph). Redistribution of hatched larvae among replicates within each treatment was carried out on $0 \mathrm{dph}$ to give an equal stocking density of 4 larvae $\mathrm{l}^{-1}$ in each tank.

Feeding density of 2000 prey $\mathrm{l}^{-1}$ of natural zooplankton was maintained by $24 \mathrm{~h}$ filtration of adjacent seawater using a Hydrotech size-selective filter system (Seljeset et al. 2010). The larvae were initially fed with zooplankton with a size fraction of 80-250 $\mu \mathrm{m}$ and this was gradually increased to $350-500 \mu \mathrm{m}$.

Handling of animals in the mesocosm experiment was conducted using the animal experimentation permit ID2346 granted by the Animal Welfare Committee as determined under the Norwegian Animal Welfare Act.

\section{Fish sampling and otolith preparation}

Fish larvae were sampled 8 times from 7 dph until 46 dph (at 7, 11, 14, 18, 25, 32, 39 and 46 dph). Sampling through the whole water column was done by dropping a PVC pipe with a manual closing mechanism to the bottom of the tanks, obtaining 3 to 12 larvae in each scoop. Point sampling close to the water surface was later implemented when it became harder to catch the larvae using the PVC pipe. Each fish larva was photographed in a thin film of seawater in $<30 \mathrm{~s}$ and frozen individually in Eppendorf tubes at $-80^{\circ} \mathrm{C}$. Standard length (SL) of the fish larvae was measured using the calibrated pictures. The 
lapilli and sagittae were dissected from the fish larvae using fine needles and mounted on glass slides using CrystalbondTM 509. Pictures were taken of each otolith using an Olympus BX61 compound microscope. Most of the pictures of the otoliths were taken using an oil immersion objective (1000x magnification), while larger otoliths from older larvae were taken at 200 to $600 \times$ magnification. The otolith surface area and dimensions were measured from the pictures of the otoliths using ImageJ software (Schneider et al. 2012).

\section{Analysis}

The otolith surface area was compared among treatments using analysis of covariance (ANCOVA), with fish SL used as the covariate to account for differences in fish length among fish larvae and dependence of otolith size on fish size (Otterlei et al. 2002). Data from all of the larvae in the 3 replicate tanks of each treatment were treated as one group because there were no significant differences among the replicates within each treatment. Otolith surface area was log-transformed in 2 age groups (32 and $46 \mathrm{dph}$ ) to meet the ANCOVA assumption of homogeneity of regression slopes among the $3 \mathrm{pCO}_{2}$ treatments, which is required to test for intercept (otolith area) differences. Regression slopes among treatments were not significantly different in the rest of the age group.

In Atlantic cod, an ontogenetic shift in the growth rates of the sagitta and lapillus takes place, with larger lapilli at the earlier larval stages and then a shift to larger sagittae in later stages. Bergstad (1984) reported that the shift in the growth rates of sagitta and lapillus occurred at $\sim 25 \mathrm{dph}$ or $6 \mathrm{~mm}$ SL. This transition was monitored in the present study by tracking changes in the ratio of the surface area of the sagitta to that of the lapillus for each fish larva. The sagitta/lapillus surface area ratios were compared among $\mathrm{pCO}_{2}$ treatments per sampling date using nested ANOVA, with tanks nested in $\mathrm{pCO}_{2}$ treatments. A non-parametric Kruskal-Wallis test was performed for those sampling dates when the sagitta/lapillus surface area ratios did not satisfy assumptions for normality and homogeneity of variance. The same procedure for nested ANOVA and Kruskal-Wallis test was performed on fish SL data.

Differences in otolith surface area between the right and left sides, referred to as fluctuating asymmetry (Somarakis et al. 1997), were derived for each larva when both right and left otoliths were avail- able. Higher variability was hypothesized in the high $\mathrm{CO}_{2}$ treatment. The differences between the 2 sides were normalized by dividing by the mean otolith surface area of the 2 otoliths and then plotted against age of the larvae. The homogeneity of variances of the fluctuating asymmetry with age among the $\mathrm{pCO}_{2}$ treatments was tested using Hartley F-max tests of homogeneity of variances.

The shape of the lapilli and sagittae was also compared using the roundness parameter derived from the otolith pictures using ImageJ. A value of 1 means a perfect circle, while values approaching 0 indicate an increasingly elongated shape (Schneider et al. 2012). A nested ANOVA was used to compare otolith roundness among the $\mathrm{pCO}_{2}$ treatments with replicate tanks nested in each treatment. The individual roundness value from both the left- and right-side otoliths was included in the analysis.

\section{RESULTS}

Increases in the growth of both lapillus and sagittal otoliths were observed in 7 to $46 \mathrm{dph}$ cod larvae (Fig. 1). Larger otolith surface areas were observed in the high, followed by the medium and control treatments. The otolith surface area of larvae in the medium treatment fluctuated between values of the control and high treatments. The greatest difference in mean otolith surface area (ANCOVA adjusted with fish length) was at $11 \mathrm{dph}$, when the sagittae of larvae from the medium and high treatments were 46 and $43 \%$ larger than the control group, respectively.

An ontogenetic shift in the growth rates of the lapilli and sagittae was observed in all larvae (Fig. 2). The lapillus was initially larger than the sagitta, then the growth of the sagitta overtook that of the lapillus. However, the timing of the shift in the sagitta/lapillus surface area ratio occurred earlier, at $32 \mathrm{dph}$, for larvae from the high treatment compared to the larvae from control and medium treatments. At 11 and $18 \mathrm{dph}$, the high treatment larvae already showed significantly higher sagitta/lapillus surface area ratios than those in the control and medium treatments even though the shift in growth rates had not yet occurred. At $32 \mathrm{dph}$, the larvae in the high treatment were $>6 \mathrm{~mm}$ SL and significantly longer than larvae in the control and medium treatments (Fig. 3). This trend of SL with increasing $\mathrm{pCO}_{2}$ was seen at 11, 25 and $32 \mathrm{dph}$.

The left- and right-side otoliths often differed in size (Fig. 4), but there was no bias to indicate directional asymmetry or increase in the magnitude of the 


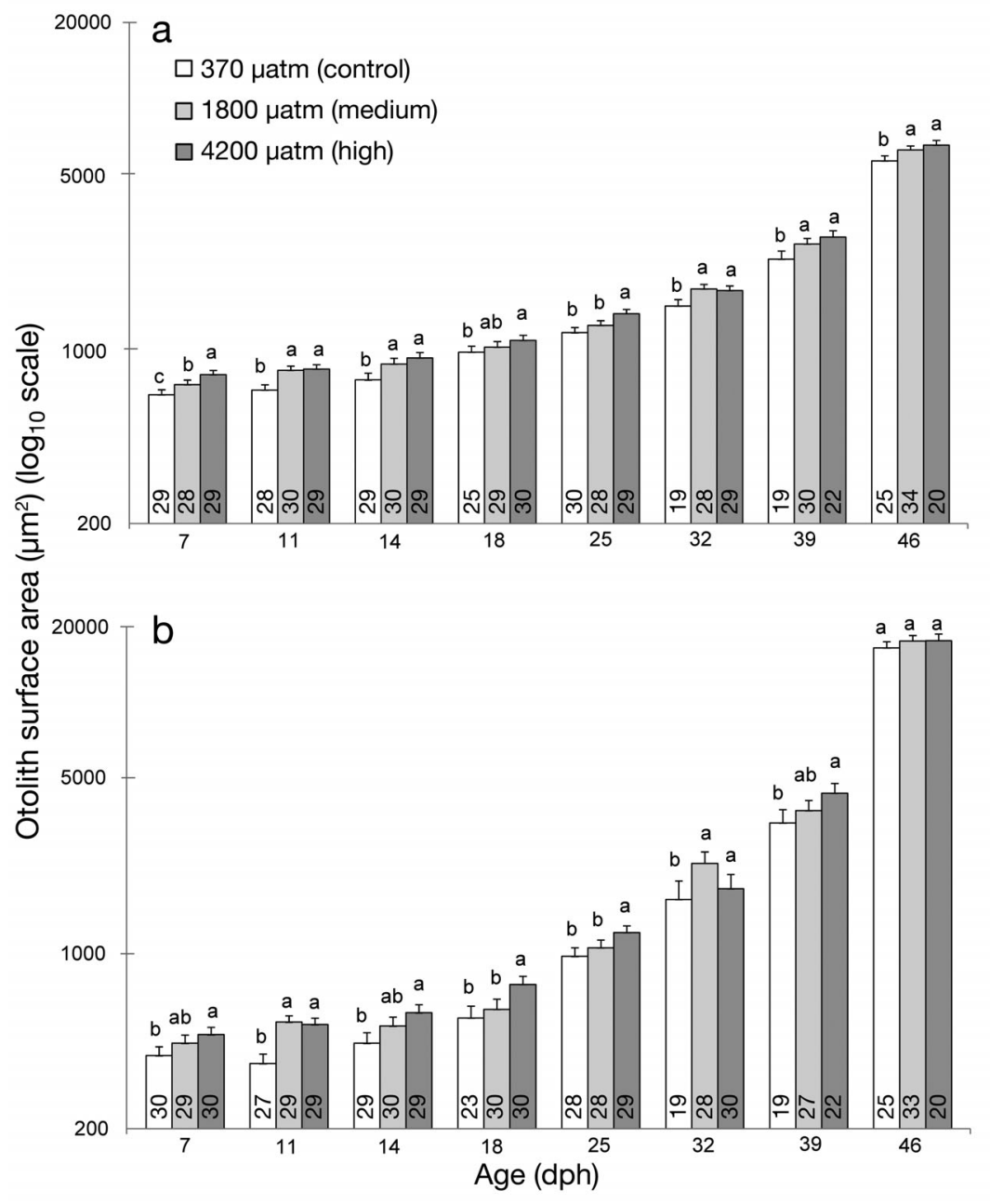

Fig. 1. Gadus morhua. Mean (ANCOVA-adjusted) surface area of (a) lapilli and (b) sagittae (both normalized to fish standard length [SL]) from Atlantic cod larvae grown in $3 \mathrm{pCO}_{2}$ treatments. Whiskers denote $95 \%$ CI. Different letters above bars denote significant differences between $\mathrm{pCO}_{2}$ treatments based on ANCOVA test with SL as the covariate (at $5 \%$ significance level). Numbers inside bars indicate sample sizes; dph: days post-hatch

no clear $\mathrm{pCO}_{2}$ treatment effect on the shape of the sagitta except at $25 \mathrm{dph}$, when more rounded sagittae were associated with increased $\mathrm{pCO}_{2}$ (nested ANOVA, $\mathrm{p}=0.016$ ).

\section{DISCUSSION}

Our results show that otoliths of Atlantic cod larvae ( 7 to $46 \mathrm{dph}$ ) were larger in elevated $\mathrm{pCO}_{2}$ conditions. Increase in otolith growth began early in development ( $7 \mathrm{dph}$ ). Several studies have already explored the possibility of enhanced calcification under elevated $\mathrm{pCO}_{2}$ conditions in marine organisms with active acid/ base regulatory mechanisms. High ambient $\mathrm{pCO}_{2}$ could result in respiratory acidosis where extracellular $\mathrm{pCO}_{2}$ rises and $\mathrm{pH}$ decreases (Melzner et al. 2009). In organisms that regulate acid-base balance, respiratory acidosis is counteracted by elevating the levels of bicarbonate $\left(\mathrm{HCO}_{3}{ }^{-}\right)$in the blood and extracellular spaces, which in turn brings the $\mathrm{pH}$ closer to the normal level (Marshall \& Grosell 2005, Melzner et al. 2009). Cuttlefish minimized the decrease in extracellular blood $\mathrm{pH}$, decreasing by only 0.18 units, when subjected to acute hypercapnia at $0.60 \mathrm{kPa} \mathrm{pCO}_{2}$ (Gutowska et al. 2010a). This extracellular pH regulation in cuttlefish was achieved through active ion-transport processes, which rapidly increased extra-

fluctuation. Variances of the differences in otolith area between right and left sides with age were homogenous amongst $\mathrm{pCO}_{2}$ treatments (Hartley Fmax: lapillus 1.28 , sagitta $2.33, \mathrm{p}>0.05$ ).

The mean roundness values of the lapillus from 7 to 39 dph ranged from 0.91 to 0.94 and did not differ among the $\mathrm{pCO}_{2}$ treatments (nested ANOVA, p > 0.05) (Fig. 5). By $46 \mathrm{dph}$, the mean roundness values of the lapillus decreased significantly compared to the younger larvae, with otoliths from the medium and high treatments having a significantly more elongated shape than those from the control group (nested ANOVA, p < 0.001). For the sagittal otoliths, the roundness values increased from 7 to $32 \mathrm{dph}$ but became more elongated again at $46 \mathrm{dph}$. There was cellular $\mathrm{HCO}_{3}{ }^{-}$from $3.38 \mathrm{mM}$ to $9.8 \mathrm{mM}$ within $8 \mathrm{~h}$ and stabilized at $10.4 \mathrm{mM}$ after $24 \mathrm{~h}$. Similarly, Atlantic cod (230 to $525 \mathrm{~g}$ ) showed an increase of $21 \mathrm{mM} \mathrm{HCO}_{3}{ }^{-}$in the blood over $24 \mathrm{~h}$ when exposed to $1.10 \mathrm{kPa}$ (Larsen et al. 1997). The increase in $\mathrm{HCO}_{3}{ }^{-}$in the blood of cuttlefish and the partial compensation of extracellular $\mathrm{pH}$ could have increased the $\mathrm{CaCO}_{3}$ saturation state, thereby resulting in elevated calcification rates of the cuttlebone under longterm elevated $\mathrm{pCO}_{2}$ conditions (Gutowska et al. 2008, 2010b). In teleost fishes, Payan et al. (1998) demonstrated that blood $\mathrm{pH}$ in unstarved fish shows a significant positive relationship with the endolymph pH, while Mugiya \& Takahashi (1985) reported higher $\mathrm{pH}$ and total $\mathrm{CO}_{2}$ in the endolymph compared 


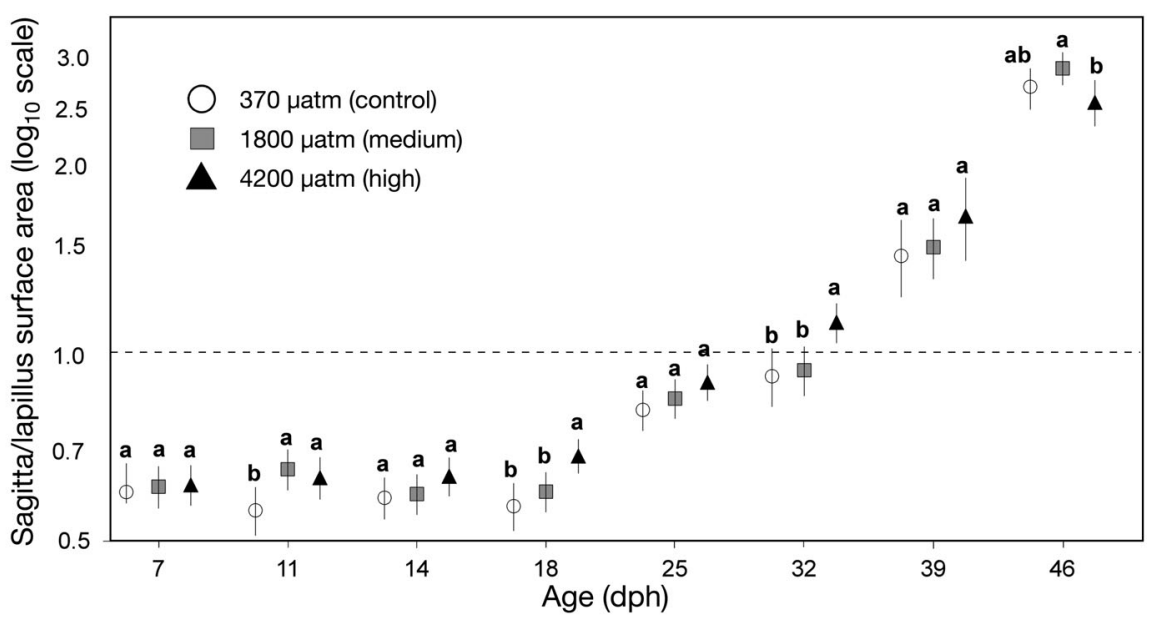

Fig. 2. Gadus morhua. Sagitta/lapillus surface area ratio of otoliths from cod larvae grown under $3 \mathrm{pCO}_{2}$ concentrations. Whiskers denote $95 \%$ CI. Different letters above whiskers denote significant differences between $\mathrm{pCO}_{2}$ treatments based on nested ANOVA or Kruskal Wallis test, if necessary (at $5 \%$ significance level)

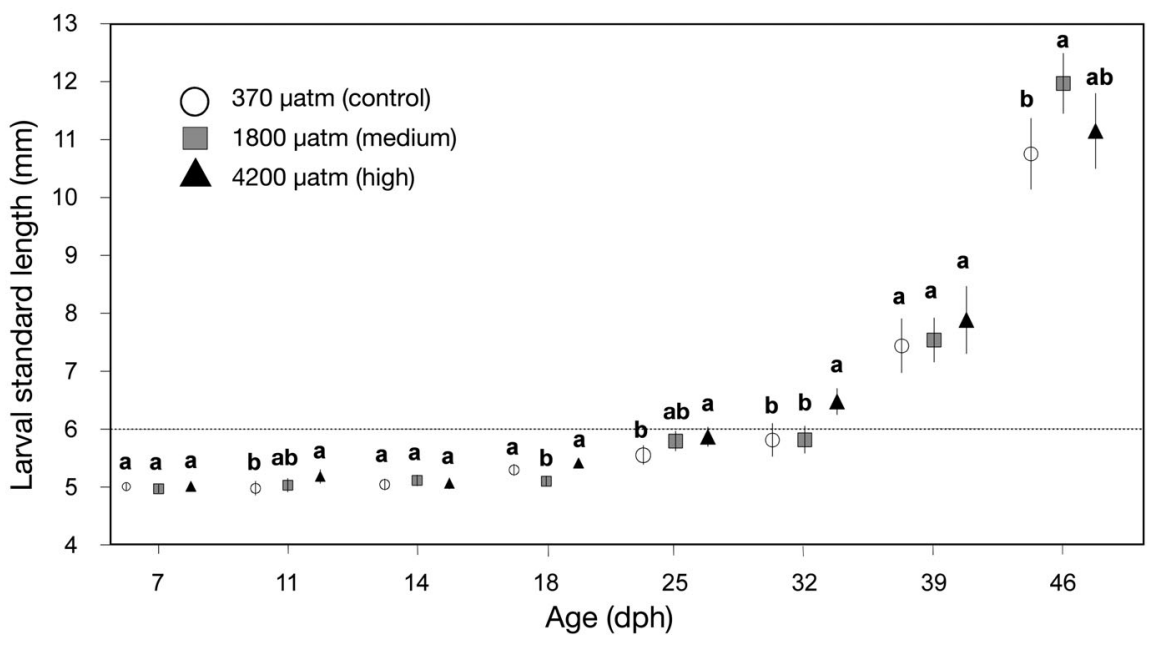

Fig. 3. Gadus morhua. Standard lengths of cod larvae grown under $3 \mathrm{pCO}_{2}$ concentrations. Whiskers denote $95 \%$ CI. Different letters above whiskers denote significant differences between $\mathrm{pCO}_{2}$ treatments based on nested ANOVA or Kruskal Wallis test, if necessary (at $5 \%$ significance level)

to plasma. Thus, maintenance of high $\mathrm{pH}$ in the blood during hypercapnia could also be translated into higher $\mathrm{pH}$ in the endolymph. The hypercalcification observed in larval clownfish Amphiprion percula at $1721 \mu \mathrm{atm} \mathrm{pCO}_{2}$ (Munday et al. 2011a) and in white seabass larvae at 993 and $2558 \mu \mathrm{atm} \mathrm{pCO}_{2}$ (Checkley et al. 2009) was attributed to $\mathrm{pH}$ regulation in the otolith endolymph. Payan et al. (1998) provided the evidence that at an endolymph pH of 7.7 to 8 , most of the total $\mathrm{CO}_{2}$ is in $\mathrm{HCO}_{3}{ }^{-}$form, which acts as the main source for $\mathrm{CaCO}_{3}$ precipitation onto the otoliths.
Thus, this could be the mechanism causing the increase in otolith growth at elevated $\mathrm{pCO}_{2}$ levels in our study.

Acid-base regulation by branchial or gill respiration was not yet functional in most of the cod larval stages in our study, especially the younger larvae. Structures that aid in effective gill ventilation, such as the opercular bones, only start to form at 40 to $50 \mathrm{dph}$ (Hunt von Herbing et al. 1996). However, the increase in otolith growth in cod larvae at elevated $\mathrm{pCO}_{2}$ suggests an already effective acidbase regulation by cutaneous respiration in the early larval stages. Acid-base regulation by raising the $\mathrm{HCO}_{3}{ }^{-}$concentrations might be just enough for the $\mathrm{pH}$ compensation required to counteract acidosis and consequently cause more precipitation of calcium carbonate into the otolith structure. Functional acid-base regulation even at early stages in cod larvae could have been aided by the presence of accessory respiratory structures, such as the pseudobranch, a structure with a large volume of blood cells and thin epithelial lining positioned in the head of cod larvae, and pigmented hemoglobin in the red blood cells (Mattey et al. 1978, Hunt von Herbing et al. 1996, Marshall \& Grosell 2005).

Otoliths are the main organs for detecting acceleration, balance and sound in fish. Increase in the growth of otoliths due to elevated $\mathrm{pCO}_{2}$ could have consequences on the otolith functions. Huelsenbeck (2010) reported less swimming activity in white seabass larvae grown at $\mathrm{pCO}_{2} 2500$ patm coincident with occurrence of hyper-calcified otoliths. However, cod larvae aged 12 and $27 \mathrm{dph}$ from our experiment showed only subtle changes in their swimming behavior due to increased $\mathrm{pCO}_{2}$ concentration (Maneja et al. 2012). Changes in otolith growth due to projected and extreme local ocean acidification events might not translate to behavioral changes in fish larvae. 


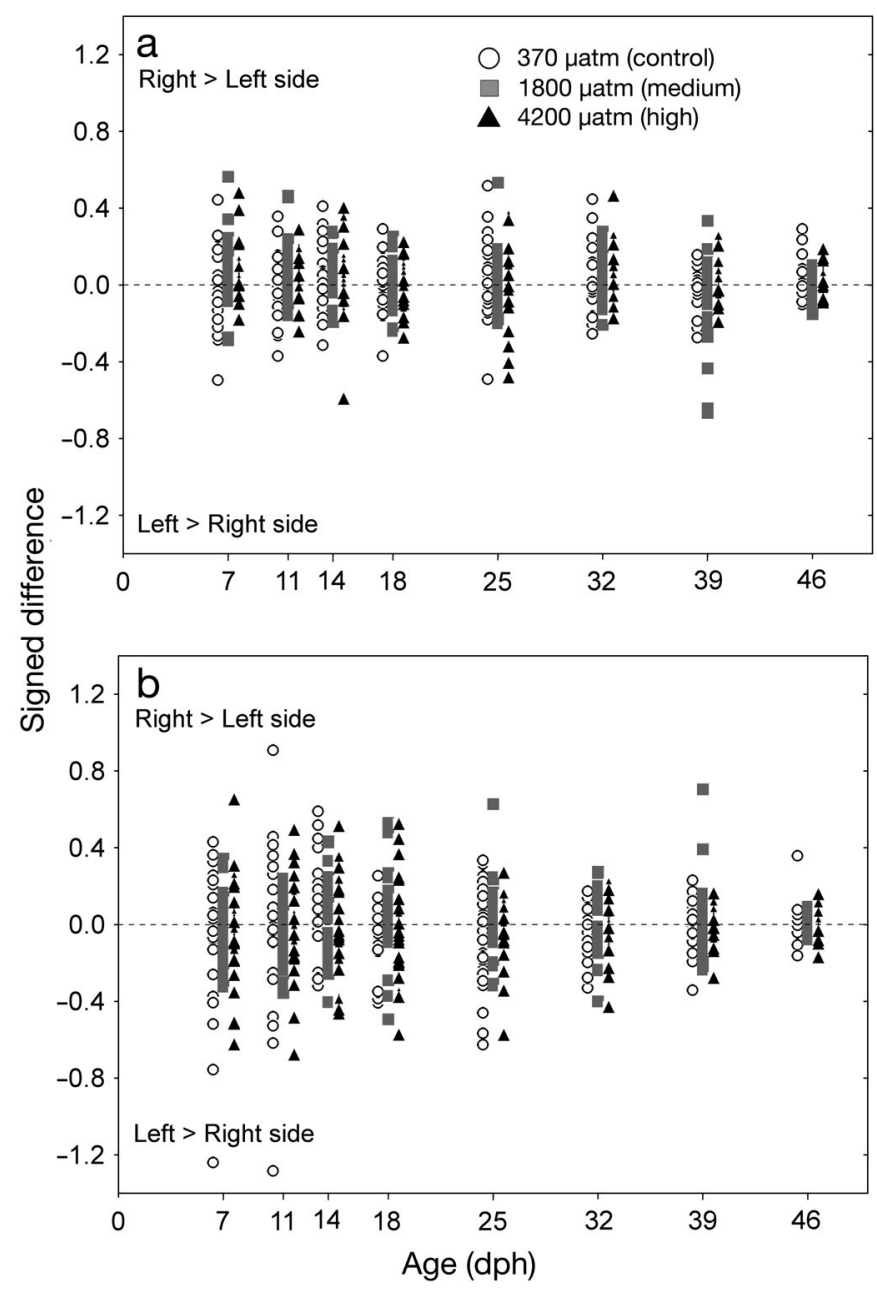

Fig. 4. Gadus morhua. Signed difference of otolith surface area ([right-left]/mean) of Atlantic cod larvae grown under $3 \mathrm{pCO}_{2}$ concentrations. Signed difference was normalized by dividing by the mean surface area of the 2 sides. Offset in the $x$-axis was used to display the data per $\mathrm{pCO}_{2}$ treatment. (a) Lapilli, (b) sagittae

Reports on larvae of tropical marine fishes point to disruptions of neurotransmitter functions in the brain due to elevated levels of $\mathrm{HCO}_{3}{ }^{-}$concentrations in the blood as the main cause of behavioral changes under ocean acidification events (Nilsson et al. 2012). The behavioral changes in fish larvae included damage to olfaction causing loss of homing ability (Munday et al. 2009), loss of detection and avoidance of predators (Dixson et al. 2010, Munday et al. 2010) and loss of predatory reaction to presence of prey (Cripps et al. 2011). The impairment of the neurotransmitter function might also have affected the ability of the larvae to decide between left and right turns (Domenici et al. 2012) and caused a loss of ability to learn anti-predatory responses (Ferrari et al. 2012). Despite the possible increase in $\mathrm{HCO}_{3}{ }^{-}$concentration in the endolymph as a consequence of $\mathrm{pH}$ compensation, implied from increased otolith growth with elevated $\mathrm{pCO}_{2}$, only subtle changes in the swimming behavior of cod larvae from the same experiment were reported by Maneja et al. (2012). It is important to investigate if the disruption in the neurotransmitter functions in fish larvae due to the effects of ocean acidification (Nilsson et al. 2012) is observable only at the end-points of behavioral cue experiments (e.g. reaction to predator) and not on the specific swimming kinematic variables. For example, a fish larva that is attracted to the smell of a predator might still be swimming normally under acidified seawater conditions. It is worthwhile investigating implications of the subtle behavioral changes in cod larvae with enhanced otolith growth from elevated $\mathrm{pCO}_{2}$ in behavioral cue experiments, such as reaction to the presence of predators and changes in food densities.

Another interesting result from the present study was the earlier transition of the growth rates of the sagittae and lapilli in the high treatment, which occurred at $32 \mathrm{dph}$, compared to the medium and control treatments at $39 \mathrm{dph}$. The differences in the timing of transition in the growth rates of the lapilli and sagittae could have been an indirect effect of the observed differences in the somatic growth rate of the larvae. Bergstad (1984) reported that the lapilli of cod larvae reared at $5 \pm 1^{\circ} \mathrm{C}$ were always larger than the sagittae from hatching until $\sim 6 \mathrm{~mm}$ SL or at $\sim 25$ dph. Dale (1984) also reported bigger lapilli than sagittae in the early larval stage of cod. In the present study, the mean SL of the larvae from the high treatment had already surpassed $6 \mathrm{~mm} \mathrm{SL}$, and was significantly longer than the control and medium treatments, at $32 \mathrm{dph}$. Cod larvae from the high treatment also had significantly greater dry weights than fish in the control group at $32 \mathrm{dph}$, as previously reported by Frommel et al. (2012).

Although increased otolith growth was observed in both lapilli and sagittae at elevated $\mathrm{pCO}_{2}$ levels, there was no systematic pattern of deviation from the normal fluctuating asymmetry and no severe changes in otolith shape. There was a similar and low magnitude of fluctuation of otolith growth between the right and left sides (fluctuating asymmetry) in all treatments. These findings support the earlier report by Munday et al. (2011a) on the maintenance of otolith symmetry and shape despite an increase in otolith growth at $1721 \mu \mathrm{atm} \mathrm{pCO}_{2}$. This 


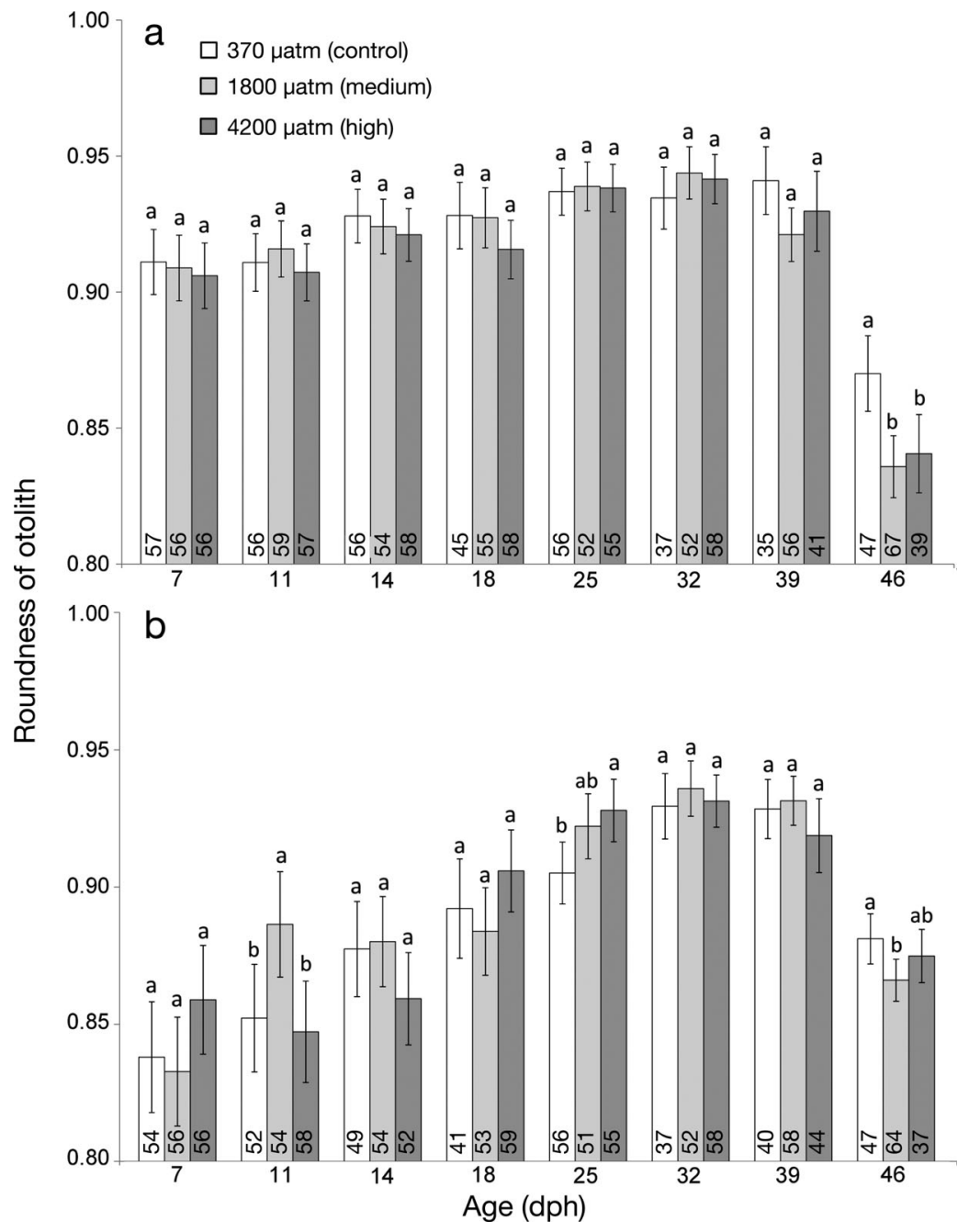

Fig. 5. Gadus morhua. Mean roundness of (a) lapilli and (b) sagittae from cod larvae grown under $3 \mathrm{pCO}_{2}$ concentrations. Whiskers denote $95 \% \mathrm{CI}$. Different letters above whiskers denote significant differences between $\mathrm{pCO}_{2}$ treatments based on nested ANOVA (at 5\% significance level). Roundness values range from 0 (highly elongated) to 1 (perfect circle). Numbers inside bars indicate sample sizes temporal processing and sound localization, were shown through mathematical modeling to be affected by increasing otolith mass asymmetry, particularly those involving large otolith masses.

In summary, the present study showed that under conditions mimicking global and locally enhanced ocean acidification, otolith growth in Atlantic cod larvae increased and size-related transition in lapillus and sagittal growth rates occurred earlier than under normal conditions. However, the magnitude of fluctuating asymmetry did not increase, nor did it lead to directional bias in otolith growth or to severe damage in otolith shape. The increase in otolith calcification due to elevated $\mathrm{pCO}_{2}$ might be well within the natural variation in otolith sizes maintaining normal functioning.

Acknowledgements. Funding support was provided through the European Community's Seventh Framework Programme (FP7/2007-2013) under the Marie Curie Initial Training Network 'Calcification by Marine Organisms' (CalMarO) and the RTD project 'European Project on Ocean Acidification' (EPOCA, grant agreement N211384). The study was also supported by the project 'Biological Impacts of Ocean ACIDification' (BIOACID), funded by the German Ministry for Education and Research (BMBF). The experiments were conducted at the Norwegian National Mesocosm Centre, Espegrend, in cooperation with the Department of Biology, University of Bergen.

\section{LITERATURE CITED}

could also mean that changes in the carbonate magnitude in both left and right sides. The subtle deviations from bilateral symmetry in otolith size have been recommended as an indicator of condition in larval fish, where negative reactions to stress events are recorded as increased levels of fluctuating asymmetry (Somarakis et al. 1997). Lychakov \& Rebane (2005) suggested that a specific physicochemical mechanism of the paired otolith growth must exist, allowing teleost fishes to minimize the fluctuation in otolith masses between the left and right otoliths for proper acoustic functionality. Acoustic functionality of the fish, such as sensitivity,
Aguirre WE (2003) Allometric growth of the sulcus in Cynoscion spp. (Sciaenidae). J Fish Biol 63:1341-1346

Asplin L, Salvanes AGV, Kristoffersen JB (1999) Nonlocal wind-driven fjord-coast advection and its potential effect on plankton and fish recruitment. Fish Oceanogr 8 : 255-263

> Bates NR, Mathis JT, Cooper LW (2009) Ocean acidification and biologically induced seasonality of carbonate mineral saturation states in the western Arctic Ocean. J Geophys Res 114:C11007, doi:10.1029/2008JC004862

Bergstad OA (1984) A relationship between the number of growth increments on the otoliths and age of larval and juvenile cod, Gadus morhua L. In: Dahl E, Danielssen DS, Moksness E, Solemdal P (eds) The propagation of cod, Gadus morhua L. An international symposium. 
Flødevigen rapportser, Part 1. Institute of Marine Research, Arendal, p 251-272

Campana SE (2005) Otolith science entering the 21st century. Mar Freshw Res 56:485-495

> Checkley DM Jr, Dickson AG, Takahashi M, Radich JA, Eisenkolb N, Asch R (2009) Elevated $\mathrm{CO}_{2}$ enhances otolith growth in young fish. Science 324:1683

Cripps IL, Munday PL, McCormick MI (2011) Ocean acidification affects prey detection by a predatory reef fish. PLoS ONE 6:e22736

Dale T (1984) Embryogenesis and growth of otoliths in the cod (Gadus morhua L.) In: Dahl E, Danielssen DS, Moksness E, Solemdal P (eds) The propagation of cod, Gadus morhua L. An international symposium. Flødevigen rapportser, Part 1. Institute of Marine Research, Arendal, p 231-250

$>$ Degens ET, Deuser WG, Haedrich RL (1969) Molecular structure and composition of fish otoliths. Mar Biol 2: 105-113

Dixson DL, Munday PL, Jones GP (2010) Ocean acidification disrupts the innate ability of fish to detect predator olfactory cues. Ecol Lett 13:68-75

Domenici P, Allan B, McCormick MI, Munday PL (2012) Elevated carbon dioxide affects behavioral lateralization in a coral reef fish. Biol Lett 8(1):78-81

> Fabry VJ, McClintock JB, Mathis JT, Grebmeier JM (2009) Ocean acidification at high latitudes: the bellwether. Oceanography (Wash DC) 22:160-171

Ferrari MCO, Manassa RP, Dixson DL, Munday PL and others (2012) Effects of ocean acidification on learning in coral reef fishes. PLoS ONE 7:e31478

Findlay HS, Tyrrell T, Bellerby RGJ, Merico A, Skjelvan I (2008) Carbon and nutrient mixed layer dynamics in the Norwegian Sea. Biogeosciences 5:1395-1410

> Frommel AY, Maneja RH, Lowe D, Malzahn AM and others (2012) Severe tissue damage in Atlantic cod larvae under increasing ocean acidification. Nature Climate Change 2:42-46

Furnes GK, Sundby S (1981) Upwelling and wind induced circulation in Vestfjorden. In: Sæetre R, Mork M (eds) The Norwegian Coastal Current. Proc Norw Coast Curr Symp. University of Bergen, p 152-177

Gauldie RW (1988) Function, form and time-keeping properties of fish otoliths. Comp Biochem Physiol A 91:395-402

Gutowska MA, Pörtner HO, Melzner F (2008) Growth and calcification in the cephalopod Sepia officinalis under elevated seawater $\mathrm{pCO}_{2}$. Mar Ecol Prog Ser 373:303-309

Gutowska MA, Melzner F, Langenbuch M, Bock C, Claireaux G, Pörtner HO (2010a) Acid-base regulatory ability of the cephalopod (Sepia officinalis) in response to environmental hypercapnia. J Comp Physiol B 180:323-335

Gutowska MA, Melzner F, Pörtner HO, Meier S (2010b) Cuttlebone calcification increases during exposure to elevated seawater $p \mathrm{CO}_{2}$ in the cephalopod Sepia officinalis. Mar Biol 157:1653-1663

Huelsenbeck M (2010) The effects of elevated carbon dioxide concentrations for the larval behavior of white seabass, Atractoscion nobilis. MS thesis, Scripps Institution of Oceanography, University of California San Diego, La Jolla, CA

Hunt von Herbing I, Miyake T, Hall BK, Boutilier RG (1996) Ontogeny of feeding and respiration in larval Atlantic cod Gadus morhua (Teleostei, Gadiformes): I. Morphology. J Morphol 227:15-35

Larsen BK, Pörtner HO, Jensen FB (1997) Extra- and intracellular acid-base balance and ionic regulation in cod (Gadus morhua) during combined and isolated exposures to hypercapnia and copper. Mar Biol 128:337-346
Lombarte A (1992) Changes in otolith area: sensory area ratio with body size and depth. Environ Biol Fishes 33:405-410

Lychakov DV, Rebane YT (2005) Fish otolith mass asymmetry: morphometry and influence on acoustic functionality. Hear Res 201:55-69

- Maneja RH, Frommel AY, Browman HI, Clemmesen C and others (2012) The swimming kinematics of larval Atlantic cod, Gadus morhua L., are resilient to elevated seawater $p \mathrm{CO}_{2}$. Mar Biol doi:10.1007/s00227-012-2054-y

Marshall WS, Grosell M (2005) Ion transport and osmoregulation in fish. In: Evans D (ed) The physiology of fishes. CRC Press, Boca Raton, FL, p 177-230

> Mattey DL, Moate R, Morgan M (1978) Comparison of 'pseudobranch type' and 'chloride type' cells in the pseudobranch of marine, freshwater and euryhaline teleosts. J Fish Biol 13:535-542

Melzner F, Gutowska MA, Langenbuch M, Dupont S and others (2009) Physiological basis for high $\mathrm{CO}_{2}$ tolerance in marine ectothermic animals: pre-adaptation through lifestyle and ontogeny? Biogeosciences 6:2313-2331

Mugiya Y, Takahashi T (1985) Chemical properties of the saccular endolymph in the rainbow trout, Salmo gairdneri. Bull Fac Fish Hokkaido Univ 36:57-63

> Munday PL, Dixson DL, Donelson JM, Jones GP, Pratchett MS, Devitsina GV, Doving KB (2009) Ocean acidification impairs olfactory discrimination and homing ability of a marine fish. Proc Natl Acad Sci USA 106:1848-1852

Munday PL, Dixson DL, McCormick MI, Meekan M, Ferrari MCO, Chivers DP (2010) Replenishment of fish populations is threatened by ocean acidification. Proc Natl Acad Sci USA 107:12930-12934

> Munday PL, Hernaman V, Dixson DL, Thorrold SR (2011a) Effect of ocean acidification on otolith development in larvae of a tropical marine fish. Biogeosciences 8: 1631-1641

> Munday PL, Gagliano M, Donelson JM, Dixson DL, Thorrold SR (2011b) Ocean acidification does not affect the early life history development of a tropical marine fish. Mar Ecol Prog Ser 423:211-221

Nilsson GE, Dixson DL, Domenici P, McCormick MI, Sorensen C, Watson SA, Munday PL (2012) Near-future carbon dioxide levels alter fish behavior by interfering with neurotransmitter function. Nature Climate Change 2:201-204

> Otterlei E, Folkvord A, Nyhammer G (2002) Temperature dependent otolith growth of larval and early juvenile Atlantic cod (Gadus morhua). ICES J Mar Sci 59:851-860

- Payan P, Borelli G, Boeuf G, Mayer-Gostan N (1998) Relationship between otolith and somatic growth: consequence of starvation on acid-base balance in plasma and endolymph in the rainbow trout Oncorhynchus mykiss. Fish Physiol Biochem 19:35-41

Schneider CA, Rasband WS, Eliceiri KW (2012) NIH Image to ImageJ: 25 years of image analysis. Nature Methods 9: 671-675

> Seljeset O, Vollset K, Folkvord A, Geffen AJ (2010) The role of prey concentration and size range in the growth and survival of larval cod. Mar Biol Res 6:251-262

> Somarakis S, Kostikas I, Tsimenides N (1997) Fluctuating asymmetry in the otoliths of larval fish as an indicator of condition: conceptual and methodological aspects. J Fish Biol 51(Suppl A):30-38

> Thomsen J, Gutowska MA, Saphörster J, Heinemann A and others (2010) Calcifying invertebrates succeed in a naturally $\mathrm{CO}_{2}$-rich coastal habitat but are threatened by high levels of future acidification. Biogeosciences 7: 3879-3891

Submitted: May 15, 2012; Accepted: October 29, 2012

Proofs received from author(s): February 24, 2013 